\title{
Walking as Precarious Public Pedagogy
}

\author{
Kimberly Powell
}

Pennsylvania State University, State College, United States of America

\begin{abstract}
This paper is located in extensive walking and narrative community-based research in the historic and ethnic neighborhood of San Jose Japantown, California, in the United States (U.S.). I consider public pedagogy through precarity, drawing from scholars who theorize the term through an ethics and politics of vulnerability, indiscernibility and relationality. In my consideration of walking as precarious public pedagogy, I work with a concept of movement as the gatherings of varying temporalities across histories, activities, humans, and nonhuman agents to underscore the entanglement of US social and economic infrastructures, discriminatory practices of spatialized place politics, and local narratives situated in place politics. I also consider the paradoxical relationship of constraints and possibilities inherent in precarity, arguing that a consideration of walking as precarious public pedagogy is indeterminant, a becoming that is entangled within a vulnerable existence.
\end{abstract}

\section{Keywords}

Asian American studies; Japanese American internment; narrative; precarity; redlining

\section{Funding acknowledgement}

Funding for this research was made possible through a Research Partnership granted through the Social Science and Humanities Research Council of Canada and through the Arts and Design Research Incubator, The Pennsylvania State University. 
PJ, Tom, Susan, and I are sitting in Roy's Station, a café in the heart of San Jose's Japantown located in California. We have been planning a large, performative walking event to be held as a special, off-site event as part of the annual meeting of the American Anthropological Association. Community members PJ, Tom, and Susan would lead a mindful, silent, and sensory walk through Japantown to listen to resident stories and to experience the place firsthand. The event is to be held the next morning. Susan is wearing a dust mask and speaks in raspy tones. All of us are concerned about holding the event outside. The largest fire ever to rage across California has created a dangerous, toxic air quality. We are sitting and talking in defeated tones, brainstorming options other than cancellation.

Kim: So, given that we can no longer hold our walking event outside due to air quality, what if we hold it in the museum?

Looks are exchanged between PJ, Tom and Susan. Kim waits for their response.

A long pause ensues.

Tom: It's a historical museum that primarily focuses on the Japanese American internment and their installations are about that experience. We respect what they do there, but we want this event to show people that we are more than that experience. We want people to know about other stories, too.

The above episode occurred as part of StoryWalks, a three-year community-based project ${ }^{\mathrm{i}}$ that engaged multigenerational residents in walking curations of their town, engaging in personal stories that entangle with public spaces, narratives and places. Tom's sentiment, expressed above, is the crux around which I develop this paper. Drawing from Story Walks research, in this paper I address questions regarding the concept of public: who enacts public pedagogy, for whom, and how, with reference to the multiplicity inherent in publics even when popularly conceived as a coherent community. I consider public pedagogy through precarity, drawing from scholars who theorize the term through an ethics and politics of vulnerability, indiscernibility and relationality. In my consideration of walking as precarious public pedagogy, I work with a concept of movement as the gatherings of varying temporalities across histories, activities, humans, and nonhuman agents, rather than something solely located in the human body as it walks and talks.

\section{Stories $\leftarrow \rightarrow$ Walks: Precarious Public Pedagogy}

The concept of public pedagogy has undergone significant expansion as fields outside of formal education research have begun to embrace and theorize pedagogy as a lens through which to examine intersections of culture, society and social change (e.g. Hickey-Moody, Savage, \& Windle, 2010). Here, publics and communities are conceived of as pedagogues capable of engaging with place as critical educators (Brady, 2006; Sandlin, Burdick \& Rich, 2017). As such, the term pedagogy has been applied to diverse sites and contexts-homes, streets, gardens and buildings, and the activities to be found there such as cooking, walking, weeding and working - often to challenge institutional norms and broaden concepts of educational practice. Sandlin, Burdick and Rich (2017) argue that, despite this criticality, the ethics and problems of both enacting and researching public pedagogy have been under-explored. They recognize and advocate a critical view of public pedagogy, wherein pedagogy is not only assumed as a transmission of norms from society to an individual but also presents an opportunity to examine and disrupt such norms (Hickey-Moody et al., 2010). Moreover, the public often becomes conceived of in totalizing ways, masking issues of differential access, opportunities or knowledge that individuals within publics might have (Savage, 2010, 2014). 
Scholars have also critically asked who gets to enact the work of public pedagogy in the name of public intervention, a concept that often appears alongside of, and synonymous with, public pedagogy. Acknowledging these challenges, Sandlin et al. (2017) interrogate the who and the how of a public pedagogue, as well as the ends that such interventions serve.

Such questions signal an ethics and politics embedded in public pedagogy that I address through the concept of precarity. Precarity names the political condition of neoliberal capitalism as that which thrives on instability, on the ways in which the precariousness of life is exploited through the social and economic conditions of disparity and inequality that capitalism creates. Different theoretical directions have yielded multiple meanings of precarity (e.g. Puar, 2012; McCormack \& Salmenniemi, 2016; Zymbalas, 2019), and I draw largely from feminist and anthropological scholars who address precarity as an ontological position that rests on indeterminacy, vulnerability, and responsibility (e.g., Berlant, 2011; Butler, 2004, 2012, 2016; Haraway 2016; Puar, 2012; Tsing, 2016). The connection between precarity and pedagogy has been previously established (Fisher, 2011; Tinning, 2018; Zembylas, 2019), building on Judith Butler's $(2004,2012)$ theory of precarity. Butler defines the term as both ontological (inherent to the human condition) and situational (located in the politics of the body), each connoting fragility, exposure, interdependency and vulnerability. Notably, Butler conceptualizes precarity through the concept of ambivalence. Precarity is not premised on notions of sameness, universality, or equality; rather, it is a vulnerability that is differentially distributed and relational. Jennifer Fisher (2011) has developed precarious pedagogy as an educational intervention based upon Butler's concept of precarity and Sara Ahmed's (2004) notion of affective economies, that which is produced through constellations of power that define a subject's location and circulate through discourses of regulation. A precarious pedagogy, she argues, acknowledges education as a political and affective project connected to social conditions and public life, and is a pedagogy without guarantees (versus a pedagogy of mastery). Michalinos Zembylas (2019) recognizes implications for a critical pedagogy for precarity, challenging the very ambivalent nature of the concept as a paradox of constraints and possibilities, and calls for educators to reframe precarity so that the possibilities and perils of a universal moralizing of economic and social relationships can be examined in relation to the ways in which vulnerability is differentially distributed. Further, Katrine Tinning (2018) acknowledges the nexus of ontology and situatedness inherent in vulnerability-a key concept in Butler's theory of precarity—suggesting a pedagogy of vulnerability for teaching-learning relations in museum pedagogy that might encourage ethical transformation.

While these arguments for precarious pedagogies highlight the relevance of precarity for educational practice, they locate the concept of pedagogy within schools or institutions, and within particular constructs and constraints of teaching and learning. Bringing together concepts of precarity and pedagogy with movement disrupts the location and construct of pedagogy. Precarity and movement have been brought together through more-than-human conceptions of both terms. Working with assemblage theory, Deleuze and Guattari (1980/1987), Jasbir Puar (2012) and Anna Tsing (2016) have written about ontological assemblages that take into account precarity, interdependency, capacity, sustainability, and multiple temporalities in which conjunctures arise from common histories as well as from "unexpected convergences and moments of uncanny coordination" (Tsing, 2016, p. 205). Moreover, vulnerability is an affective encounter that circulates among all matter rather than being lodged in the human body. For example, Tsing's methodological approach, in her study of the matsutake mushroom, is to follow lifelines and connections that weave in and across nations, regions, and local landscapes. She attends to polyphonic encounters of dissonance and harmony that are created together in open-ended gatherings, or assemblages. 
Through such encounters, she argues, new possibilities arise, taking alternative or new directions. Tsing's approach to precarity's movement embraces multiple rhythms and temporalities not configured solely through and by human movement, but also through history, nonhuman matter, and nonlinear conjunctures.

Movement is considered in similar ways in the walking methodologies of Stephanie Springgay and Sarah E. Truman (2018), who theorize movement as not just located in pedestrian walking, but as something inherent in all matter: always differentiating and emergent. Through their work with trans theories, they conceptualize movement as "flows, vectors, and affective tonalities" (p. 60). Movement is also explored in relation to pedagogy via the work of Nikki Rotas and Stephanie Springgay (2013) who theorized pedagogy as a 'politics to come,' framing politics as a material, relational, and movement-oriented understanding of pedagogy via affect, movement and touch. Another example is Springgay's (2011) "Chinatown Foray" artist walk as a sensory pedagogy, undergirded by theories of affect and movement theorized via Deleuze and Guattari (1980/1987), Brian Massumi (2002), and Erin Manning (2006). Springgay's research highlights movement as constituted by unfolding, emergent qualities of experience that have yet to enter into cognitive perception and are thus open to differential possibility.

Taking these different theoretical orientations to precarity and movement into consideration, the remainder of this paper highlights walking's precarious public pedagogy in my Story Walks research in Japantown. I diagram precarity's movement as affective and constitutive of multiple temporalities configured through more than human nonlinear conjunctures.

\section{The StoryWalks Project}

StoryWalks is a research project that involves asking residents, and those who have significant business or recreation interests, to take me on a walk of a historic neighborhood known as Japantown, San Jose, California (U.S.). The neighborhood is about 0.26 square miles with notable business and residential zones. The research is a collaboration with artist PJ Hirabayashi, a long-time resident and co-founder of a residential performance group, San Jose Taiko, founded in 1973 with her husband, Roy, and a few others.

The 1942 Presidential Executive Order Number 9066, which relocated Japanese American citizens to Japanese internment camps across the United States, many of which were built in secluded desert-like areas, is a significant historical event for the Story Walks project. The numbers of affected citizens are estimated at around 110,000. San Jose Japantown is a significant community because, out of 53 businesses that were forced into closure during internment, 40 businesses and 100 families reestablished themselves by 1947, three years following the revoked policy. ${ }^{\text {ii }}$ The internment experiences have been archived through media, texts, museums, historical societies, activism, civic organizations, the Smithsonian Institute's photographic archives, and the U.S. National Park Service (e.g. the Manzanar War Relocation Center is now a National historic site).

Today, approximately 3500 residents live in Japantown, many of whom are Japanese American, Chinese American, Filipino American, and Latino American. It is home to The Japanese American Museum of San Jose (JAMSJ), which houses archives from the forced relocation and internment, including an installation of a barracks created by a resident of Japantown who was interned as a young man. Additionally, it includes numerous historical plaques, signs, public memorials, and art installations that refer to immigration, settlement, internment, and individuals who resided in the town. These sites serve as forms of public pedagogy in that they are explicitly designed by residents and civic planning boards to teach those embarking on self-conducted or docent-led tours of the town. There is also an annual 
Day of Remembrance hosted by the neighborhood's Buddhist Church, where guest speakers from civil rights groups, politicians and those who were incarcerated speak in remembrance. As part of this event, there is a candlelit, silent walk through the main street of the town that circles back to the Church.

The historical event of mass, ethnic incarceration and internment has produced a narrative of the priaisinecariousness of livelihood, freedom, civil rights, ethnicity, place, and economics that functions as public pedagogy through docent tours, public speeches, public walking events, memorials and installations. Initially, my community research partner, PJ Hirabayashi, and I thought we would work solely with the already-established docent walking tours hosted by JAMSJ, in order to think about the ways in which docent tours function pedagogically. The tours are led by volunteers, a few of whom experienced the internment first-hand, and thus imbue their tours with a combination of an overarching historical narrative and personal stories. We realized, however, that there were multiple stories across generations of people living in Japantown, beyond those already captured by docent-led tours, and that we had the opportunity to hear from many residents across generations and ethnic communities.

Throughout the three-year project, we walked and talked with about 30 people, aged 591, video recording each walk. StoryWalkers have included three museum docents who experienced internment, women and men in their twenties and thirties, a retired police officer, a festival choreographer responsible for overseeing the large annual Obon Festival held in Japantown, a documentary filmmaker, business owners, a long-time Chinese American couple known for bringing Wing Chun martial arts to Japantown, the president of the Filipino American historic society, a class of five year-old children attending the Buddhist preschool in Japantown, and a Latino mural artist who owns a gallery in the neighborhood. Key to our research is that Japantown has a multiplicity of ethnicities residing in it, and as such our research not only focuses on Japanese internment, but on a critical understanding of place.

We started most of the walks with a walking tour question that would prompt personal stories: "If you were to give me a tour of Japantown, where would you take me/us, and why?" We wondered about the pedagogical potential inherent in such a question. Early on, it became evident that these individual walks were curational practices of place-based storytelling. They were shaped by public, formalized, historic narratives of Asian American immigration, segregation, and Japanese American internment. In fact, the individual walking narratives produced in our research became an opportunity to rethink public pedagogy in Japantown.

\section{Susan's StoryWalk}

Susan's StoryWalk is illustrative of the entanglement of public, formalized narratives with local and situated stories that illustrates the paradoxical relationship of constraints and possibilities inherent in precarity's social, political and economic positioning of Othering (Lorey, as cited in Puar, 2012). Susan, in her sixties, is a self-described 'civil liberties' activist in the Japanese American community. She walked and talked with me for over an hour, along several places in the neighborhood that she described as important sites for those interested in social change. A few, vivid examples of precarity's paradox are presented in the following examples from the walk. One of the first sites she took me to was the Issei Memorial Building, now a San Jose Historic Landmark. Nearly all 30 residents took PJ and I there as part of their StoryWalks. Built in 1910, the building served as the Kuwabara Hospital, named after its first resident physician, who served there until 1934. Anti-Asian sentiment and religious, cultural and language differences are cited as barriers for Japanese residents and immigrants to attend the main hospital in San Jose, which resulted in a need for a hospital 
within Japantown. Japanese doctors were not legally licensed in the state of California, so Dr. Taisuke Kuwabara was supervised by a White, licensed doctor, James Beattie, who also held the title at the hospital.

Susan's walk didn't include all of that information. Instead, she offered a nuanced, contemporary account of how the hospital functioned as a space of possibility:

I'm not a docent [from the local museum] that gives a walking tour, but I'm sure people have told you that this used to be a hospital. Look at all the people who are in this building now (she points to a sign, reading off some of the organizations that have offices in the building): San Jose Chapter of the Japanese American Citizens League (JACL), San Jose Taiko offices, and the Contemporary Asian Theater Scene and Teatro Visión. This shows the multicultural aspect of Japantown.... It's really providing — it's giving birth (she laughs) to a lot of community organizations. That's another reason why a physical space is so important. You know that people can come here and just by accidentally running into each other can come up with ideas, and work on things, and develop ideas about the future of the community.

Walking and talking provided an occasion for both planned and unplanned movement to buildings and sites, as the act of walking allowed for emergent connections to be made: the Japanese American Museum of San Jose; Yu-Ai Kai Senior Center; a polished granite memorial carved with a timeline of Japanese American events and common phrases of the Issei generation; a bar called Bamboo 7 and its role in intergenerational meetups and conversations; the former office of the Asian Law Alliance; and the site of an old pharmacy, which is now a Mexican restaurant.

Susan's walk pertained to both physical and conceptual spaces: memories pertaining to her political involvement since the 1970s. The internment experience, for example, was mentioned several times as were other critical events, such as the historic redlining of the neighborhood. "I think redlining is the unofficial way that segregation was enforced," Susan stated. "It was an arrangement between mortgage lenders and realtors to keep housing segregated." She recounted how she saw a computerized, interactive redlining map from 1933 of San Jose, and how the Japantown area was the only redlined area in the city of San Jose at that time. "And the realtors' notes were very interesting, very telling," she adds. "They said, 'This area has too many negroes and orientals':"

I think it's really important to understand that Japantowns (in San Jose, San Francisco, and Los Angeles) didn't arise ... just to provide ethnic interest for people. They were because of segregation and for mutual support for communities and social interactions for people.

Susan is referring to an illegal practice that the Federal Housing Administration (FHA) engaged in during the 1930s in the face of a housing shortage, a practice that Richard Rothstein (2017) notes was a state-sponsored system of segregation. The term 'redlining' derives from the practice of drawing a red line on a map to delineate the area where financial institutions would not invest or back mortgages based on racial, ethnic and religious composition without regard to residents' qualifications or creditworthiness. ${ }^{\text {iv }}$ The area in San Jose known as Japantown was a redlined neighborhood. In this excerpt, as well as the prior one regarding the hospital, Susan's stories - as they entangle with historical narratives of precarity's social, political and economic Othering-revealed precarity's paradoxical relation of constraints and possibilities. Susan's walking narratives revealed vulnerability as an affective encounter circulating among all matter: an assemblage of discourses, policies, economics, neighborhood borders, and forced and voluntary movements across multiple temporalities. 
The constraints and possibilities inherent in inequitable social, political and economic policies, and the situatedness of the body politics in terms of its exposure, vulnerability, and interdependency, become clearer when she discussed her involvement in the Nihonmachi Outreach Committee (NOC) in 1979. Her stories spoke of the physical spaces in the neighborhood, gestured to buildings no longer there, or to other buildings that were now occupied in different ways than how they had functioned during the past. She also storied walking down the main street: "I mentioned that I had come here to join the Nihonmachi committee meeting to talk about redevelopment, and I have to say I did not understand that issue. It's kind of an urban planning, economic, and political issue." She describes how, at 22, growing up in white suburban Orange County, California, she did not have a strong understanding of the history of the redevelopments of the different Japantowns:

And, um, for me, the concept of having a physical space was pretty foreign. I didn't even really understand it. When I was growing up, the place I could be Japanese was in my family's home. So actually, in some ways, that now helps me really understand what the value of what a physical Japantown is. It's nice to have a place where you can go outside and feel comfortable. And having a tie to not only the buildings but the history and the people. (...) Redevelopment didn't do it for me (in terms of understanding the importance of a physical place). But an issue that was coming up in 1979 was the issue of redress and reparations for [the internment of] Japanese Americans. And that I understood. That hit me really hard. I really wanted to be part of that.

Standing in front of an arching, tall, white memorial of an etched timeline of events in Japantown, which included the internment, Susan moved from a discussion of the memorial to personal accounts of the NOC's informational programs concerning what they felt were reasonable demands for redress.

We found former internees that were willing to host a house meeting. We would show our slide shows - in those days we had little slide machines - and we chose slides about the history of the camps and demands for redress and we'd ask people who had hosted and friends or family members they invited: "What was your experience?" And it was so moving because a lot of people, if you think about this, hadn't talked about it at all, for like 30 years. And a lot of times, those meetings were, people just cried. But it started to break through. More and more people started to be willing to talk. (...) We were trying to organize people to go to the commission hearings, the commission on wartime relocation and internment of civilians were having hearings about the camps. So, we were trying to find people who were willing to go testify.

From the memorial, Susan walked with me to the local museum that houses historical archives. She recounted how, in order to encourage people to talk and remember, she, along with NOC members, asked people to bring things that they had brought home from camp; many brought artwork or documents such as leave clearances and IDs. These items became part of an exhibit for the redress campaign, which, years later, became institutionalized as part of the museum. Susan saw a direct tie between the redress movement and building community institutions in which personal, local items become curated as part of public history.

Susan's repeated references to the importance of places and spaces for gatherings, political redress, collective remembering, and activism-where creative responses were made possible-were produced through structures of violence that cross space-time scales and registers of intensity. This is demonstrable of living with the conditions of precarity, and that which it makes possible in precarity's vulnerable and unstable condition. Towards the end of the walk, I raised an issue that we had discussed earlier that morning, pertaining to a comment 
made by a Trump supporter on a television news show, who had cited the Japanese American internment as a rationale for the establishment of a Muslim American registry (Bromwich, 2016). Crossing registers again, Susan gestures toward the street we are standing on:

I see this place in striking contrast. We have this wonderful community. It's so human and normal here. People here deserve to be treated as real, multi-faceted human beings. ... Those scapegoating political bloviations are an enemy to normal Americans who want to live productive lives, where they are making a contribution to the general community.

Susan's walk illustrates movement across various temporalities at play in relation to histories of internment, redlining, archives, building uses, and political discourses that move across time and space and meet at conjunctures: connections arriving either through commonly shared histories as much as chance. To story encounters is not so much an event of deliberate, sequential or linear dialogue. It is to story through conjunctures (Tsing, 2016). Connections arise through encounters that physically or figuratively move and circulate on the walk and configure precarious lifelines joined across space, time and place. The experience is constitutive of happenings, sensorial surprises, past experiences, the thinking-feeling of the moment, conversations, associations, relations, physical structures, and the catching of foot on pavement. StoryWalks like Susan's emerged from rhythms in and of the world, where thought is incipient to occasion (Massumi, 2011). Facts don't hold still among these various agents. This might be recognized in the ways in which walking is relational movement, one with the world: "not a body, a world, but body-worlding," as Manning suggests (2012, p. 13).

As a precarious public pedagogy, Susan's Story Walk is a pedagogy of "becoming public" that creates a form of political existence (Biesta, 2014, as cited in Sandlin et al., 2017, p. 5). It moves the concept of pedagogy away from its typical association of cognitive transmission toward an "affective process of relationality and embodiment" (Sandlin et al., 2017, p. 6). As a public pedagogy, the public here is indeterminant: the pedagogical encounter initially occurs between Susan and me, and-as recorded material via text and video-creates an encounter with an unknown public at various times and forums. It is pedagogy that speaks to a real or imagined public (Biesta, 2014).

\section{A Walking Performance with Stories}

About a year after the end of the StoryWalks project, an opportunity came about in the form of a local conference in which we designed a public walking event in Japantown. In the opening of this paper, I described one of our planning meetings between Susan, whose StoryWalk is described above, Tom, Executive Director of the History Center at DeAnza College, who had expressed interest in the pedagogical potential of walking, and PJ, my community research partner. As fires raged across Northern California, preventing us from carrying through with our planned walk in the neighborhood due to poor air quality, we regrouped and decided to hold it in the Issei Memorial Building, the site of the former hospital and current site of cultural and social organizations. The irony embedded in this turn of events, where precarity's firey presence, fueled by global climate change, involuntarily committed us to a state of not walking. This loomed large in relation to our public pedagogical performance, which was designed to showcase the power of StoryWalking's potential.

Tom, Susan and PJ had written a script and choreographed the event around particular themes they wanted to address; we performed the walking event in a large room, with seats arranged in a circle. Tom's opening remarks summarized the intention of the event as an open-ended, creative encounter with history, place, and body politics: 
This is an experiment on our parts, and is an attempt to help think out ways to create a broader, deeper, encompassing grasp of the meaning of Japantown including all of its nuances and quirks. It is a journey for us without a complete map.

In effect, Tom, Susan and PJ created an arts-based public pedagogy that engaged with performative, aesthetic modes of pedagogy (Burdick \& Sandlin, 2013), unconcerned with a particular learning outcome or goal, but seeking to raise political and cultural questions through public interaction and togetherness (Biesta, 2014).

PJ led the 35 attendees in her sensory and mindful practices attending to walking's processual rhythms, breathing techniques to focus and clear the mind, and sensory awareness strategies that would tune perception. The presenters choreographed the 'walk' around four themes, based on specific sites in the neighborhood: exclusion and segregation; generations, heritage and legacy; a diverse and changing community; and faith-based institutions, symbols of a community's spirituality. Exclusion and segregation was materialized by three physical markers in the form of memorials and Ikoi $\mathrm{No} \mathrm{Ba}$ (translated as gathering places of rest, built on site as public installations). These markers included: an agricultural marker, a camps marker, and a civil liberties marker. Since these were immediately accessible outside the building, we let the audience walk outside briefly to encounter these sites. After they came back in, PJ facilitated walking as a performance event of walking slowly around the room, stopping at digitally projected 'sites' - photographic images of buildings that they had chosen to focus on in the walk. These projected sites connected to each of the four themes. For example, generations, heritage and legacy was represented by a photograph of the intersection of $5^{\text {th }}$ and Jackson Street, the symbolic center of Japantown, which is heavy with historic markers and art installations. Tom discussed the theme generations, heritage and legacy, which tied together the markers that exist on each of the four corners of the intersection, along with the intersection of $6^{\text {th }}$ and Jackson street, where new buildings and businesses were built on the former site of Chinatown and a Filipino American Business area. Tom and Susan told stories on the theme a diverse and changing community. Tom and Susan shared stories pertaining to the theme, faith-based institutions, symbols of a community's spirituality.

Between each of these 'sites', PJ led the participants in a deliberately slow processional that circled the room, stopping when the next image was projected onto the screen. Susan shared many of the stories that had been produced during her StoryWalk: stories about redlining, internment, activism, redevelopment and redress. A fourth speaker, Carol, a local business owner (who had given her own StoryWalk to PJ and me), came for part of the performance to share her stories of growing up in Japantown. Her talk wove together the interdependency of the community as fostered through difficult political and economic times, stories of her parent's and relative's experiences in the internment camps, and her hopes for a multicultural future that is both responsive to the community's history as well as mindful of new directions and creative possibilities.

This 'non-walking' walking event is illustrative of the affective intensity of walking's pedagogical potential, what Erin Manning (2013) refers to as affective space-time, or timeout-of-place, in excess of particular content. In considering the precarious pedagogy embedded in both Susan's StoryWalk, as well as the StoryWalk performance, we might consider what thrives in the ruins of capitalist, institutionalized racist practices. Walking through precarity highlights the affective encounters between large infrastructural ruins and personal, locally situated stories, illustrating Kathleen Stewart's contention that politics is not reducible but affective, taking place as intensities at various registers (2007, as cited in Wilson \& Yochim, 
2017). Walking's precarious public pedagogy is indeterminant, a 'becoming public with stories that create forms of movement entangled with a political, vulnerable existence.

\section{Notes and Acknowledgements}

This research was made possible through a Partnership Grant from the Social Science and Humanities Research Council of Canada and through financial support from the Penn State Arts and Design Research Incubator in the United States. The author wishes to acknowledge Stephanie Springgay, Sarah E. Truman, Andrew Hickey, and Louise Phillips as partners in the SSHRC. Acknowledgment also goes to PJ Hirabayashi, who collaborated on this threeyear study and made valuable contributions.

\section{References}

Ahmed, S. (2004). The cultural politics of emotion. New York, NY: Routledge.

Berlant, L. (2011). Cruel optimism. Durham, NC: Duke University Press.

Biesta, G. (2014). Making pedagogy public: For the public, of the public or in the interest of publicness. In J. Burdick, J. A. Sandlin, \& M. P. O’Malley (Eds.), Problematizing public pedagogy (pp. 15-26). New York, NY: Routledge.

Burdick, J., \& Sandlin, J. A. (2013). Learning, becoming, and the unknowable: Conceptualizations, mechanisms, and process in public pedagogy literature. Curriculum Inquiry, 43(1), 142-177. https://doi.org/10.1111/curi.12001

Brady, J. F. (2006). Public pedagogy and educational leadership: Politically engaged scholarly communities and possibilities for critical engagement. Journal of Curriculum \& Pedagogy, 3(1), 57-60. https://doi.org/10.1080/15505170.2006.10411575

Bromwich, J. E. (2016, November 17). Trump camp's talk of registry and Japanese internment raises Muslims' fears. The New York Times. Retrieved from https://www.nytimes.com/

Butler, J. (2004). Precarious life: The power of mourning and violence. New York, NY: Verso.

Butler, J. (2012). Precarious life, vulnerability, and the ethics of cohabitation. Journal of Speculative Philosophy 26(2): 134-151.

Butler, J. (2016). Rethinking vulnerability and resistance. In J. Butler, Z. Gambetti, and L. Sabsay (Eds.), Vulnerability in resistance (pp.12-27). Durham: Duke University Press.

Deleuze, G., \& Guattari, F. (1987). A thousand plateaus: Capitalism and schizophrenia (B. Massumi, Trans.). Minneapolis, MN: University of Minnesota Press. (Originally published 1980)

Fisher, J. (2011). "The walking wounded": Youth, public education, and the turn to precarious pedagogy. Review of Education, Pedagogy, and Cultural Studies, 33(5): 379432. https://doi.org/10.1080/10714413.2011.620858

Haraway, D. (2016). Staying with the trouble: Making kin in the Chthulucene. Durham, NC: Duke University Press. 
Hickey-Moody, A., Savage, G. C., \& Windle, J. (2010). Pedagogy writ large: Public, popular and cultural pedagogies in motion. Critical Studies in Education, 51(3), 227236. https://doi.org/10.1080/17508487.2010.508767

Manning, E. (2012). Relationscapes: Movement, art, philosophy. Cambridge, MA: MIT Press.

Manning, E. (2013). Always more than one: Individuation's dance. Durham, NC: Duke University Press.

Manning, E. (2006). Politics of touch: Sense, movement, sovereignty. Minneapolis, MN: University of Minnesota Press.

Massumi, B. (2002). Parables for the virtual: Movement, affect, sensation. Durham, NC: Duke University Press.

Massumi, B. (2011). Semblance and event: Activist philosophy and the occurrent arts. Cambridge, MA: MIT Press.

McCormack, D., \& Salmenniemi, S. (2016). The biopolitics of precarity and the self. European Journal of Cultural Studies, 19(1), 3-15. https://doi.org/10.1177/1367549415585559

Puar, J. (Ed.) (2012). Precarity Talk: A virtual roundtable with Lauren Berlant, Judith Butler, Bojana Cvejić, Isabell Lorey, Jasbir Puar, and Ana Vujanović. TDR: The Drama Review, 56(4): 163-177. https://doi.org/10.1162/DRAM a 00221

Rotas, N., \& Springgay, S. (2013). 'You go to my head': Art, pedagogy and a politics to come. Pedagogies, 8(3): 278-290. https://doi.org/10.1080/1554480X.2013.794917

Rothstein, R. (2017). The color of law: A forgotten history of how our government segregated America. New York, NY: Liveright.

Sandlin, J., Burdick, J., \& Rich E. (2017). Problematizing public engagement within public pedagogy research and practice, Discourse: Studies in the Cultural Politics of Education, 38(6), 823-835. https://doi.org/10.1080/01596306.2016.1196343

Savage, G. (2010). Problematizing 'public pedagogy' in educational research. In J. A. Sandlin, B. D. Schultz, \& J. Burdick (Eds.) Handbook of public pedagogy (pp. 103-115). New York, NY: Routledge.

Savage, G. (2014). Chasing the phantoms of public pedagogy: Political, popular and concrete publics. In J. Burdick, J. A. Sandlin, \& M. P. O’Malley (Eds.) Problematizing public pedagogy (pp. 79-90). New York, NY: Routledge.

Springgay, S. (2011). "The Chinatown Foray" as sensational pedagogy. Curriculum Inquiry, 41(5), 636-656. https://doi.org/10.1111/j.1467-873X.2011.00565.X

Springgay, S., \& Truman, S. (2018). Walking methodologies in a more-than-human world. WalkingLab. New York, NY: Routledge.

Tinning, K. (2018). Vulnerability as a key concept in museum pedagogy on difficult matters. Studies in philosophy and education, 37(2): 147-165. https://doi.org/10.1007/s11217-017-9579-y

The Fair Housing Center of Greater Boston. The historical shift from explicit to implicit policies affecting housing segregation in Eastern Massachusetts. 1934-1968: FHA 
Mortgage insurance requirements utilize redlining. Retrieved January 30, 2019 from http://www.bostonfairhousing.org/timeline/1934-1968-FHA-Redlining.html.

Tsing, A. L. (2016). The mushroom at the end of the world: On the possibility of life in capitalist ruins. Princeton, NJ: Princeton University Press.

Tuck, E., \& Mckenzie, M. (2014). Place in research: Theory, methodology, and methods. New York, NY: Routledge.

Wilson, J., \& Yochim, E.C. (2017). Mothering through precarity: Women's work and digital media. Durham, NC: Duke University Press.

Zembylas, M. (2019). The ethics and politics of precarity: Risks and productive

possibilities of a critical pedagogy for precarity. Studies in Philosophy and Education 38(1),

95-111. https://doi.org/10.1007/s11217-018-9625-4

Dr. Powell focuses on art as an educational practice and methodology of and for social change, diversity, and inclusion. Her work focuses on the aesthetic dimensions of vernacular culture, and contemporary art practices that challenge social systems through experimentation with concepts, methods, materials, forms and sites. Her current research projects include StoryWalks, an exploration into walking methodology as an artful practice of placemaking, identity and social inquiry. She has authored or edited several publications.

\footnotetext{
i StoryWalks was funded through a partnership grant by the Social Sciences and Humanities Research Council of Canada.

ii See http://www.jtown.org/cat/history-san-jose-japantown, 2014.

iii https://www.californiajapantowns.org/sj/issei-memorial-building.html

iv http://www.bostonfairhousing.org/timeline/1934-1968-FHA-Redlining.html
} 